\title{
THE RESURRECTION IN JUDAISM AND CHRISTIANITY ACCORDING TO THE HEBREW TORAH AND CHRISTIAN BIBLE
}

\author{
Scott Vitkovic \\ Howzeh Elmiyeh, Qom, Islamic Republic of Iran, p29.12.1392@gmail.com
}

\begin{abstract}
This research outlines the concept of resurrection from the ancient Hebrew Torah to Rabbinic Judaism and Christianity according to authoritative and linguistically accurate scriptures accompanied by English translations. Although some contemporary scholars are of the opinion that resurrection is vaguely portrayed in the Hebrew Torah, our research into the ancient texts offers quotes and provides proofs to the contrary. With the passing time, the concept of the resurrection grew even stronger and became one of the most important doctrines of Judaism, enjoined as one of the thirteen articles of faith by Maimonides in the Mishnah. Imitative of the Jewish concept of God reaching out to save Israelites from gehenna, Jesus' crucifixion and death for the sins of the world, resurrection on the third day, descend into the hells and subsequent rise into heavens became the essential foundation of Christianity, with Christ's resurrection as the impetus for the resurrection of those who believe in him. According to this Pauline theology, Christian faith is based upon the resurrection of Jesus and the hope for a life after death.
\end{abstract}

Keywords: Resurrection, Judaism, Christianity, Torah, Bible, Comparative Theology;

\section{INTRODUCTION}

The English word resurrection is derived from the Latin resurrectionem, nom. resurrectio, meaning 'a rising again from the dead'. It denotes a noun of action from the past participle stem of Latin resurgere, meaning 'to rise or appear again'. Greek uses the word anastasis which in the verbal form means 'to cause to stand or rise up or to raise from sleep or from the dead'.

\section{DISCUSSION}

\subsection{Resurrection in Judaism}

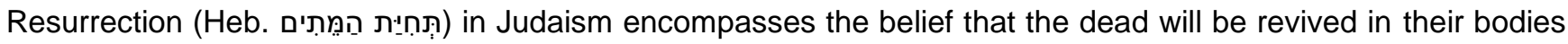


and live again on Earth. The belief in resurrection and world to come is a major tenet of the Jewish eschatology and enjoined as an article of faith in the Mishnah ${ }^{1}$. It is also included as the second benediction of the Amidah and as the last of Maimonides' Thirteen Principles of Faith (Fig.1 and 2). Every day, the Jews recite the following blessings during the Jewish liturgical prayers,

Figure 1. Maimonides Thirteen Articles of Faith

\begin{tabular}{|c|c|}
\hline $\begin{array}{l}13 \text { Articles of Faith } \\
\text { are a summary of } \\
\text { Judaism } \\
\text { - Written by the rabbi } \\
\text { Maimonides in the } \\
12^{\text {th }} \text { century CE. }\end{array}$ & $\begin{array}{l}\text { 1. God exists. } \\
\text { God is one and unique. } \\
\text { God is incorporeal. } \\
\text { God is eternal. } \\
\text { Prayer is to God only. } \\
\text { The prophets spoke truth. } \\
\text { Moses was the greatest of the prophets. } \\
\text { The Written and Oral Torah were given to } \\
\text { Moses. } \\
\text { There will be no other Torah. } \\
\text { 10. God knows the thoughts and deeds of men. } \\
\text { 11. God will reward the good and punish the } \\
\text { wicked. } \\
\text { 12. The Messiah will come. } \\
\text { 13. The dead will be resurrected. }\end{array}$ \\
\hline
\end{tabular}

Blessed are You, Lord, who causes the dead to live again (restores souls to the dead).

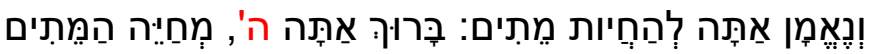

You are faithful to restore the dead to life. Blessed are You, O Lord, who brings life to the dead.

After the daily Shacharit's liturgical prayers, the following belief is reasserted,

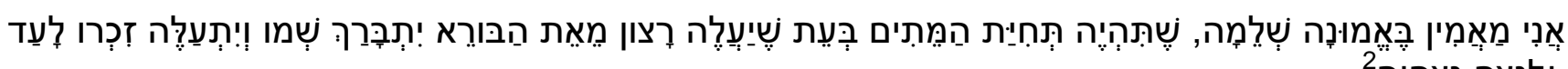

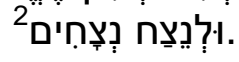

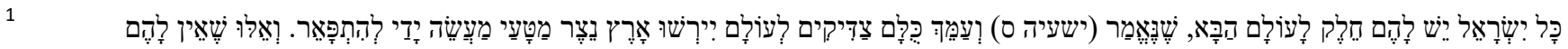

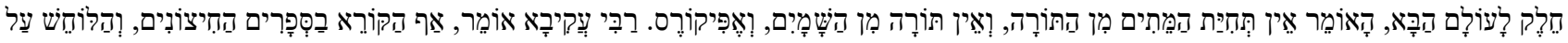

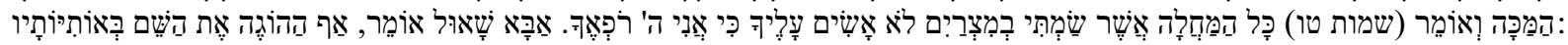
According the Sanhedrin 10:1, all faithful Jews have a share in the World to Come, as it says,

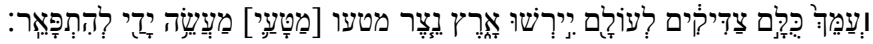
"And your people, all of them righteous, shall possess the land for all time. They are the shoot that I planted. My handiwork in which I glory" (Isaiah 60:21). These have no share in the World to Come: One who says that [the belief of] resurrection of the dead is not from the Torah, [one who says that] that the Torah is not from Heaven, and one who denigrates the Torah. Rabbi Akiva says: also one who reads outside books, and one who whispers [an incantation] over a wound, saying, (Exodus 15:26) "I will bring none of these diseases upon thee that I brought upon the Egyptians for I am the Lord that healeth thee." Abba Shaul says, also one who utters the Divine Name as it is spelled.

2 The belief in resurrection is expressed on all occasions in the Jewish liturgy; e.g., in the morning prayer Elohai Neshamah, in the Shemoneh 'Esreh, and in the funeral services. Maimonides made it the last of his thirteen articles of belief: "I firmly believe that there will take place a revival of the dead at a time which will please the Creator, blessed be His name." Saadia also, in his "Emunot we-De'ot" (following Sanh. x. 1), declared the belief in resurrection to be fundamental. Hasdai Crescas, on the other hand, declared it to be a specific doctrine of Judaism, but not one of the fundamental teachings, which view is taken also by Joseph Albo in his "Ikkarim" (i., iv. 35-41, xxiii.). The chief difficulty, as pointed out by the latter author, is to find out what the resurrection belief actually implied or comprised, since the ancient rabbis themselves differed as to whether resurrection was to be universal, or the privilege of the Jewish people only, or of the righteous only. This again depends on the question whether it was to form part of the Messianic redemption of Israel, or whether it was to usher in the last judgment. Saadia sees in the belief in resurrection a national hope, and endeavors to reconcile it with reason by comparing it with other miraculous events in nature and history recorded in the Bible. Maimonides and Albo in their commentary on Sanh. x. 1, Kimhii in his commentary on Ps. i. 5, Isaac Aboab in his "Menorat ha-Ma'or" (iii. 4, 1), and Bahya ben Asher in his commentary on Gen. xxiii. extend resurrection to the righteous only. On the other hand, Isaac Abravanel in his "Ma'yene Yeshu'ah" (ii. 9) concedes it to all Israel; Manasseh ben Israel, in his "Nishmat Hayyim" (i. 2, 8), and others, to all men. Maimonides, however (see his commentary, I.c., and "Yad," Teshubah, viii.), took the resurrection figuratively, and 
I believe with perfect faith that there will be a resurrection of the dead at the time that the Creator His name be blessed desires, and forever his presence will be known.

The resurrection of the dead is a basic principle both of the written and oral Torah of Moses. To mention only few of the many examples, the Torah states,

Figure 2. The $9^{\text {th }}$ Article of Faith of Maimonides

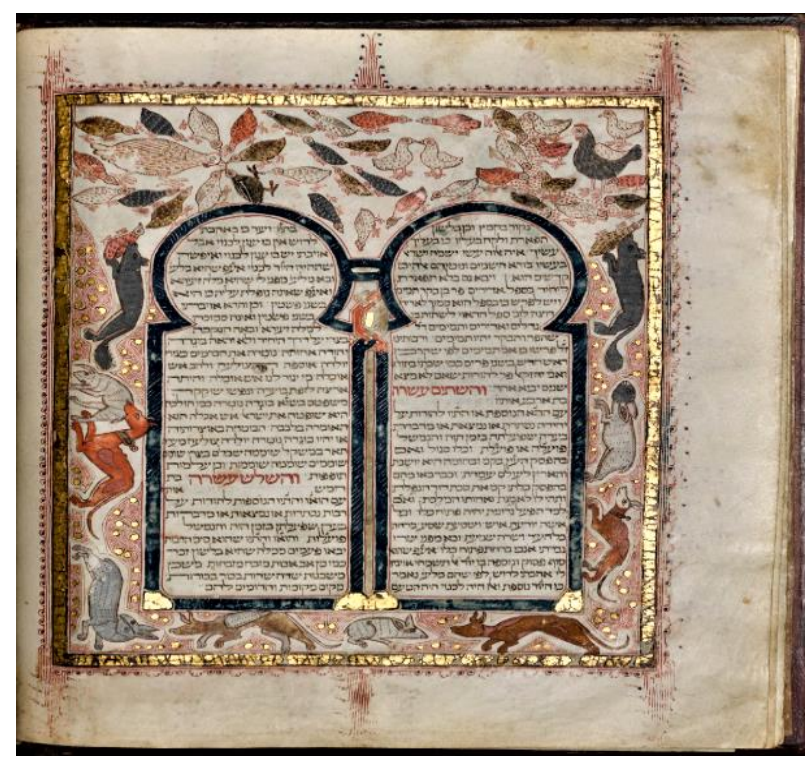

And the Lord God formed the man. (Gen. 2:7)

${ }^{4}$

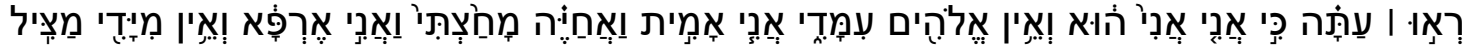
See, then, that I, I am He; There is no god beside Me. I deal death and give life; I wounded and I will heal: None can deliver from My hand. (Deut. 32:39)

Prophet Isaiah 26:19 states,

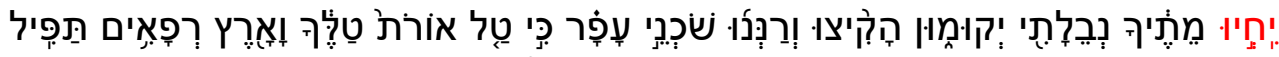
Oh, let your dead revive! Let corpses arise! Awake and shout for joy, you who dwell in the dust! For your dew is like the dew on fresh growth; You make the land of the shades come to life.

Prophet Ezekiel 37:12 states,

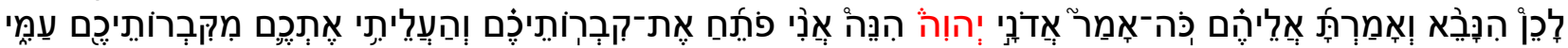

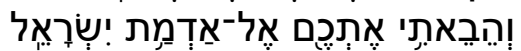
Prophesy, therefore, and say to them: Thus said the Lord God: I am going to open your graves and lift you out of the graves, O My people, and bring you to the land of Israel.

Prophet Daniel 12:2 states,

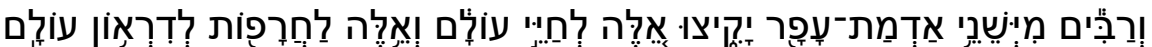
Many of those that sleep in the dust of the earth will awake, some to eternal life, others to reproaches, to everlasting abhorrence.

Rashi, in his commentary on Deuteronomy in Sifrei Devarim 47:2, says,

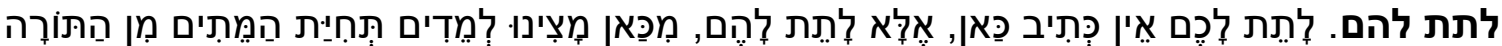
"The land which the Lord swore unto your fathers] to give to THEM" - It is not written here "to give to you" but "to give to them". Therefore, it is possible to hypothesize that the tenet of the "Resurrection of the

substituted for it immortality of the soul, as he stated at length in his "Ma'amar Tehiyyat ha-Metim"; Judah ha-Levi also, in his "Cuzari," took resurrection figuratively (i. 115, iii. 20-21).

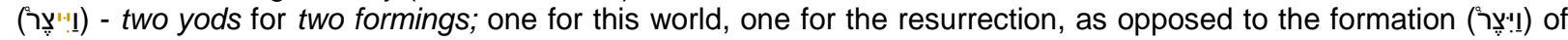
the beasts (Gen. 2:19) where only one yod is written. According to tradition, God will reconstruct the entire body from a miniscule indestructible bone in the upper spine called the luz bone when the time arrives for the Resurrection of the Dead. $4 \quad$ All quoted Pentateuch text in this manuscript is from the ancient Hebrew Torah. 
Dead" is of the Torah's origins.

Sanhedrin 92a declares,

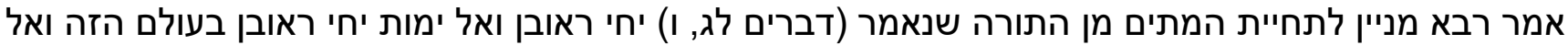

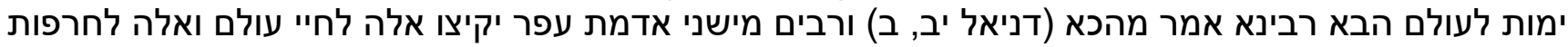

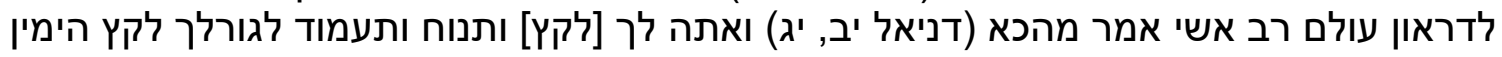

The Gemara returns to the topic of the source for resurrection in the Torah. Rava says, "From where is 'Resurrection of the Dead' derived in the Torah?" It is derived from a verse, as it is stated, "Let Reuben live and not die, in that his men become few" (Deuteronomy 33:6). This is interpreted as, "Let Reuben live [in this world] and not die [in the World-to-Comel." Ravina says that resurrection is derived from the following verse, "And many of those who sleep in the dust of the earth shall awaken, some to everlasting life, and some to reproaches and everlasting disgrace" (Daniel 12:2). Rav Ashi says proof is derived from this verse, "But go you your way until the end be; and you shall rest, and arise to your lot at the end of days" (Daniel 12:13).

While the Sadducees denied the resurrection of the $\operatorname{dead}^{5}$, the Pharisees all the more enunciated it in their liturgy $^{6}$, and established their belief in the resurrection as one of their fundamental pillars of faith ${ }^{7}$. Also, the Essenes believed in the resurrection of the body. ${ }^{8}$ However, several contemporary secular religious scholars seem to be of an opinion that the Resurrection of the Dead in Judaism is vaguely expressed in the Torah. Yet, in regards to the oral and written Torah, such a generalizing opinion seems unfounded, as many proofs testify to the fact that the Prophets of God did indeed revealed and considered resurrection of the dead as one of their fundamental beliefs.

\subsection{Resurrection in Christianity}
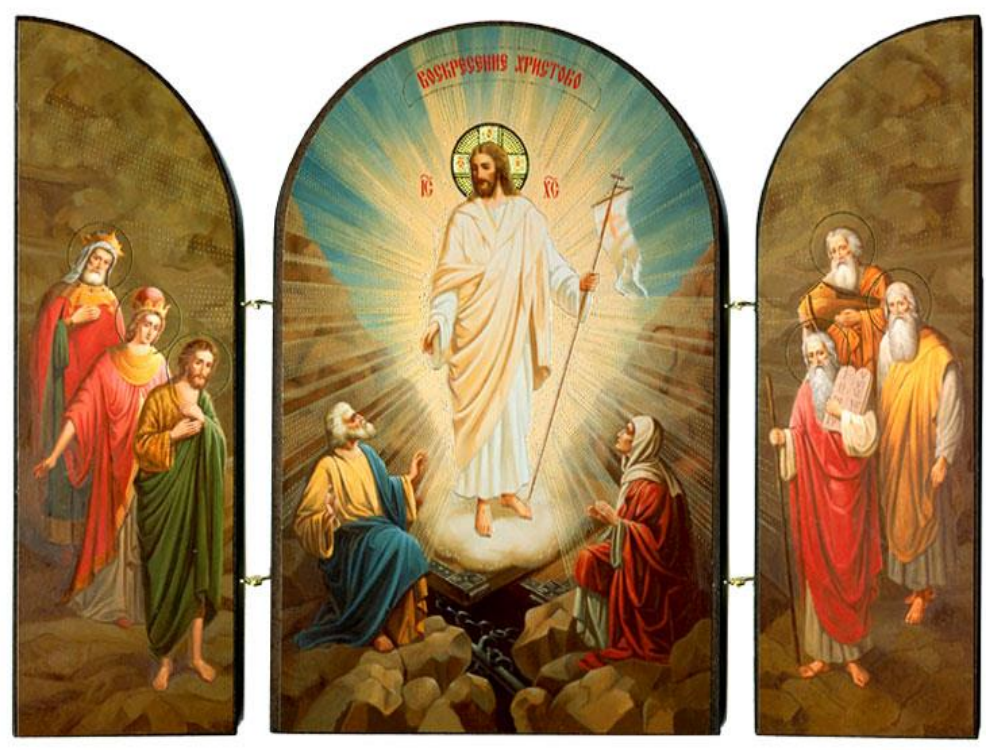

Figure 3. The Resurrection of Jesus, Christian Iconography

Imitative of the Jewish concept of God reaching out to save Israelites from Gehenna ${ }^{9}$, Jesus' crucifixion and death for the sins of the world, resurrection on the third day (Fig. 3), descend into the hells and subsequent rise

\footnotetext{
5 Josephus, "Ant." xviii. 1, § 4; idem, "B. J." ii. 8, §14; Acts xxiii. 8; Sanh. 90b; Ab. R. N. v.

6 Shemoneh 'Esreh, 2d benediction; Ber. v. 2.

7 Sanh. x. 1; comp. Abot iv. 22; Soțah ix. 15.

8 Josephus' philosophical construction of their belief to suit the taste of his Roman readers notwithstanding (see "B. J." ii. 8, § 11; "Ant." xviii. 1, § 5). Compare with the genuine source of Josephus, in Hippolytus' "Refutatio Hæresium" ed. Duncker Schneidewin, ix. 27, 29, where the original áváotaбıs [resurrection] casts a strange light upon Josephus' mode of handling texts.

9 Test. Patr., Benjamin; Sibyllines, i. 377, viii. 310; Yalk. ii. 359; Jellinek, "B. H." ii. 50 [comp. I Peter iii. 19]; Ascensio Isaiæ, iv. 21, with reference to Isa. ix. 16, lii.-liii.; see Epstein, "Bereshit Rabbati," 1888, p. 31.
} 
into the heavens is the central crux of Christianity.

The $1^{\text {st }}$ Corinthians' 15:3-4 states,

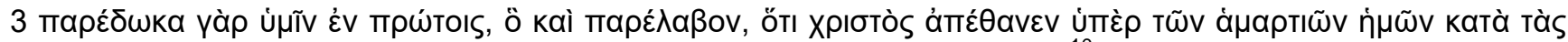

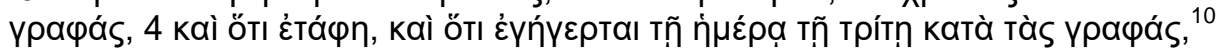

3 Tradidi enim vobis in primis quod et accepi: quoniam Christus mortuus est pro peccatis nostris secundum Scripturas: 4 et quia sepultus est, et quia resurrexit tertia die secundum Scripturas: ${ }^{11}$

3 For I delivered to you as of first importance what I also received: that Christ died for our sins in accordance with the Scriptures, 4 that he was buried, that he was raised on the third day in accordance with the Scriptures. ${ }^{12}$

And continues with 15:14-18,

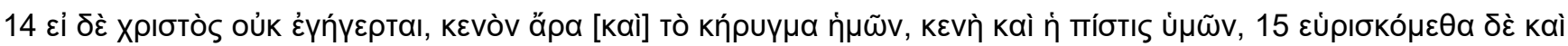

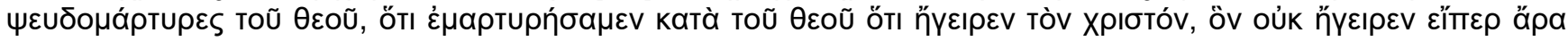

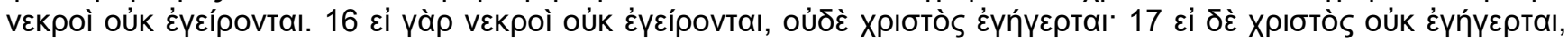

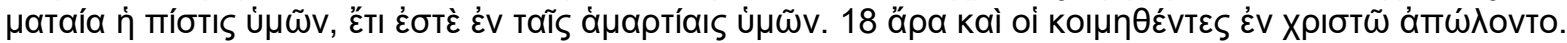

$14 \mathrm{Si}$ autem Christus non resurrexit, inanis est ergo prædicatio nostra, inanis est et fides vestra: 15 invenimur autem et falsi testes Dei: quoniam testimonium diximus adversus Deum quod suscitaverit Christum, quem non suscitavit, si mortui non resurgunt. 16 Nam si mortui non resurgunt, neque Christus resurrexit. 17 Quod si Christus non resurrexit, vana est fides vestra: adhuc enim estis in peccatis vestris. 18 Ergo et qui dormierunt in Christo, perierunt.

14 And if Christ has not been raised, then our preaching is in vain and your faith is in vain. $15 \mathrm{We}$ are even found to be misrepresenting God, because we testified about God that he raised Christ, whom he did not raise if it is true that the dead are not raised. 16 For if the dead are not raised, not even Christ has been raised. 17 And if Christ has not been raised, your faith is futile and you are still in your sins. 18 Then those also who have fallen asleep in Christ have perished.

The basis of the New Testament and Christian salvation rests in Christ's resurrection, meaning that Jesus not only rose from the dead and is alive but also guarantees that all who believe in him will likewise rise from their graves to the everlasting life. The Gospel of John 3:16-18, states,

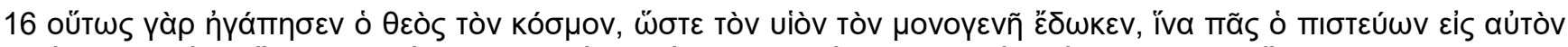

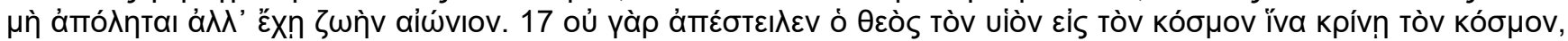

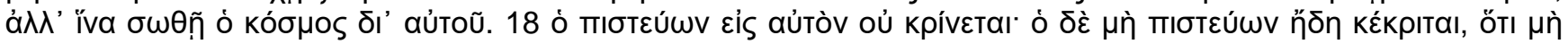

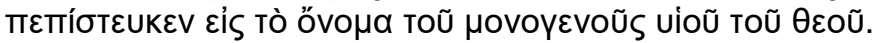

16 Sic enim Deus dilexit mundum, ut Filium suum unigenitum daret: ut omnis qui credit in eum, non pereat, sed habeat vitam æternam. 17 Non enim misit Deus Filium suum in mundum, ut judicet mundum, sed ut salvetur mundus per ipsum. 18 Qui credit in eum, non judicatur; qui autem non-credit, jam judicatus est: quia non-credit in nomine unigeniti Filii Dei.

16 For God so loved the world, that he gave his only Son, that whoever believes in him should not perish but have eternal life. 17 For God did not send his Son into the world to condemn the world, but in order that the world might be saved through him. 18 Whoever believes in him is not condemned, but whoever does not believe is condemned already, because he has not believed in the name of the only Son of God.

The Gospel of John 5:28-29 announces,

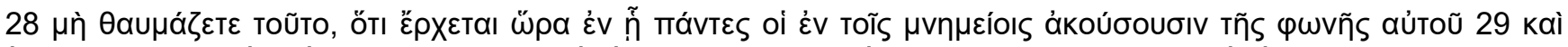

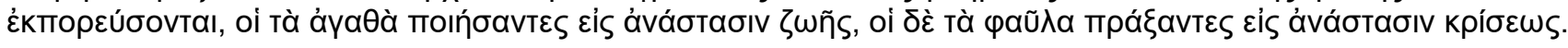

28 Nolite mirari hoc, quia venit hora in qua omnes qui in monumentis sunt audient vocem Filii Dei: 29 et procedent qui bona fecerunt, in resurrectionem vitæ; qui vero mala egerunt, in resurrectionem judicii.

10 All Greek text in this manuscript is the original Biblical text in Koine Greek.

1 All Latin text in this manuscript comes from the Septuagint.

12 All Biblical English text in the second chapter of this manuscript comes from the English Standard Version of the Bible. 
28 Do not marvel at this, for an hour is coming when all who are in the tombs will hear his voice 29 and come out, those who have done good to the resurrection of life, and those who have done evil to the resurrection of judgment.

Thereafter, the Book of Revelations 20:13-15 informs that,

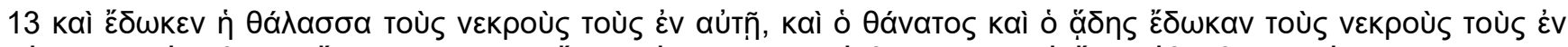

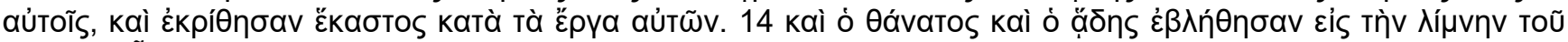

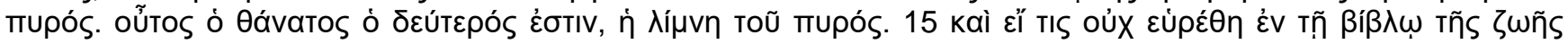

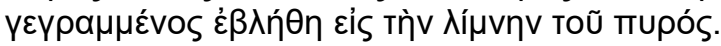

13 et dedit mare mortuos, qui in eo erant: et mors et infernus dederunt mortuos suos, qui in ipsis erant: et judicatum est de singulis secundum opera ipsorum. 14 Et infernus et mors missi sunt in stagnum ignis. Hæc est mors secunda. $15 \mathrm{Et}$ qui non inventus est in libro vitæ scriptus, missus est in stagnum ignis.

13 And the sea gave up the dead who were in it, Death and Hades gave up the dead who were in them, and they were judged, each one of them, according to what they had done. 14 Then Death and Hades were thrown into the lake of fire. This is the second death, the lake of fire. 15 And if anyone's name was not found written in the book of life, he was thrown into the lake of fire.

In Christianity, resurrection most critically concerns the Resurrection of Jesus and the Resurrection of the Dead on the Day of Judgement. ${ }^{13}$ According to the Pauline theology, Christian faith is based upon the resurrection of Jesus and the hope for a life after death.

\section{CONCLUSION}

Both Judaism and Christianity share common resurrection beliefs according to their authoritative Scriptures. While in Judaism resurrection refers to the Jewish individual in particular and to the humanity in general, Christianity is founded upon the resurrection of Jesus Christ through whom and with whom Christians will be risen to the life everlasting.

\section{REFERENCE LIST}

Charles, R. H. (1913). A critical history of the doctrine of a future life in Israel, in Judaism, and in Christianity, 2d ed. London: A. and C. Black.

Finkelstein, L. (1962). The Pharisees . Philadelphia, PA, US: The Jewish Publication Society of America.

Herberg, W. ( 1951). Judaism and Modern Man - An Interpretation of Jewish Religion. Philadelphia, PA, US: The Jewish Publication Society.

Jacobs, L. (1964). Principles of the Jewish Faith, An Analytical Study. London: Vallentine Mitchell.

Marmorstein, A. (1950). Studies in Jewish Theology. London: Oxford University Press.

\footnotetext{
${ }^{13}$ Nicene Creed
} 